\title{
Automating of Controlling Processes in Production Networks
}

\author{
JAEHN, H.; KAESCHEL, J. \& TEICH, T.
}

Abstract: Suitable methodologies and procedures are necessary for the distribution of profit or loss which has been realised by value adding processes within networked production structures. Based on the evolutionary model "Non-hierarchical regional production networks" an approach for the automated distribution of profit within Competence Cell Networks (CCN) is under development. For support purposes a Profit Distribution Broker Unit (PDBU) is applied. Thereby, practical problems such as the transaction of money, the accounting, the nondisclosure of the information about the Competence Cells (CCs) e.g. expected profit, fixed share of costs etc. arise, when a fair and automated profit distribution is aimed at. This contribution focuses that topic and presents suitable approaches and hints for realising an automated and fair profit distribution for partners in Competence Cell Network. This paper is focused different problem fields concerning non-hierarchical regional Competence Cell Networks.

Key words: Production Network, Extended Value Chain Management, Competence Cells, Network Controlling, Profit Distribution
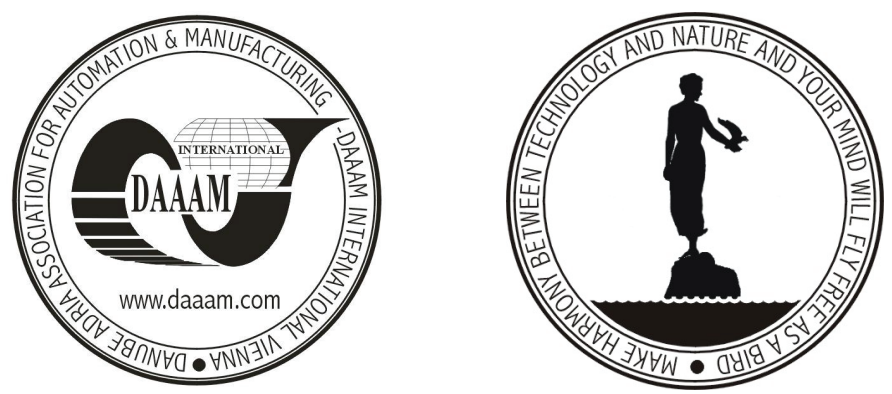

Authors' data: Dipl.-Kfm., Dipl-Vw. Jaehn H.[endrik]*, Prof. Dr. rer. nat. Dr. oec. habil. Kaeschel J.[oachim]*, Prof. Dr. rer. pol. habil. Teich T.[obias]**, *Chemnitz University of Technology, **University of Applied Sciences of West-Saxony Zwickau, Germany, hendrik.jaehn@wirtschaft.tu-chemnitz.de

This Publication has to be referred as: Jaehn, H.; Kaeschel, J. \& Teich, T. (2006). Automating of controlling processes in production networks, Chapter 23 in DAAAM International Scientific Book 2006, B. Katalinic (Ed.), Published by DAAAM International, ISBN 3-901509-47-X, ISSN 1726-9687, Vienna, Austria

DOI: $10.2507 /$ daaam.scibook.2006.23 